\title{
SPATIAL DISTRIBUTION AND ABUNDANCE OF NONINDIGENOUS CORAL GENUS Tubastraea (CNIDARIA, SCLERACTINIA) AROUND ILHA GRANDE, BRAZIL
}

\author{
PAULA, A. F. ${ }^{1}$ and CREED, J. C. ${ }^{2}$ \\ ${ }^{1}$ Laboratório de Celenterologia, Departamento de Invertebrados, Museu Nacional, \\ Universidade Federal do Rio de Janeiro, Quinta da Boa Vista, São Cristóvão, \\ CEP 20940-040, Rio de Janeiro, RJ, Brazil \\ ${ }^{2}$ Laboratório de Ecologia Marinha Bêntica, Instituto de Biologia Roberto Alcântara Gomes, \\ Universidade do Estado do Rio de Janeiro. Rua São Francisco Xavier, 524, PHLC Sala 220, \\ CEP 20559-900, Rio de Janeiro, RJ, Brazil \\ Correspondence to: Alline de Paula, Laboratório de Celenterologia, Departamento de Invertebrados, \\ Museu Nacional, Universidade Federal do Rio de Janeiro, Quinta da Boa Vista, São Cristóvão, \\ CEP 20940-040, Rio de Janeiro, RJ, Brazil, e-mail: allinefigueira@ hotmail.com \\ Received November 11, 2003 - Accepted March 31, 2004 - Distributed November 30, 2005
}

(With 6 figures)

\begin{abstract}
The distribution and abundance of azooxanthellate coral Tubastraea Lesson, 1829 were examined at different depths and their slope preference was measured on rocky shores on Ilha Grande, Brazil. Tubastraea is an ahermatypic scleractinian nonindigenous to Brazil, which probably arrived on a ship's hull or oil platform in the late 1980's. The exotic coral was found along a great geographic range of the Canal Central of Ilha Grande, extending over a distance of $25 \mathrm{~km}$. The abundance of Tubastraea was quantified by depth, using three different sampling methods: colony density, visual estimation and intercept points (100) for percentage of cover. Tubastraea showed ample tolerance to temperature and desiccation since it was found more abundantly in very shallow waters $(0.1-0.5 \mathrm{~m})$, despite the fact that hard substratum is available at greater depths at all the stations sampled. At most sites, 1 to 5 colonies per $0.25 \mathrm{~m}^{2}$ were found most frequently, but occasionally more than 50 colonies were found per $0.25 \mathrm{~m}^{2}$, indicating a somewhat gregarious spatial distribution for this coral. The coral Tubastraea was found to occupy slopes of every possible angle in the Canal Central of Ilha Grande, but more colonies were found occupying slopes of 80 to $100^{\circ}$. Therefore, its insensitivity to angles of recruitment and its tolerance for different depths makes it an organism with great ecological tolerance, with a potential to colonize new areas and increase its current range in Brazil's coastal waters.
\end{abstract}

Keywords: depth, slope, Brazil, introduction, scleractinia.

\section{RESUMO}

\section{Distribuição Espacial e Abundância do Coral Invasor Tubastraea (Cnidaria, Scleractinia) na Ilha Grande, Brasil}

A distribuição e abundância do coral azooxantelado Tubastraea Lesson, 1829 foram estimadas em diferentes profundidades e inferido seu ângulo preferencial de ocorrência em costões rochosos da Ilha Grande, Brasil. Tubastraea é um escleractínio ahermatípico introduzido no Brasil que, provavelmente, chegou incrustado em casco de navios e/ou plataformas de petróleo na década de 80 . O coral exótico foi encontrado em uma extensão geográfica de $25 \mathrm{~km}$ no Canal Central da Ilha Grande. A abundância de Tubastraea foi quantificada em relação à profundidade usando três diferentes métodos: densidade de colônias e porcentagem de cobertura por estimativa visual e pontos de intersecção. O coral Tubastraea demonstrou ter ampla tolerância à temperatura e dessecação, sendo encontrado em águas muito rasas (0,1-0,5 m), apesar de haver substrato consolidado disponível em maiores profundidades em todas as 
estações amostradas. Em todas as estações 1-5 colônias foram mais freqüentemente encontradas em cada $0,25 \mathrm{~m}^{2}$, porém, ocasionalmente, mais que 50 colônias por $0,25 \mathrm{~m}^{2}$ foram encontradas, indicando um padrão de agregação na distribuição espacial deste coral. Tubastraea foi encontrado ocupando todos os possíveis ângulos de inclinação no Canal Central da Ilha Grande, porém, a maior parte das colônias foram encontradas ocupando ângulos entre $80-100^{\circ}$. Desta forma, a amplitude de inclinação de substrato e profundidades viáveis ao recrutamento do coral indicam que este organismo, de grande tolerância ecológica, tem a potencialidade de colonizar novas áreas e aumentar sua distribuição no Brasil.

Palavras-chave: profundidade, inclinação, Brasil, introdução, scleractinia.

\section{INTRODUCTION}

Although much attention has focused on the introduction of several marine species recently (Grosholz \& Ruiz, 1996; Johnson \& Carlton, 1996; Crooks, 1998), biological invasions in marine systems have been neglected (Carlton \& Geller, 1993). The introduction of exotic species (biological invasions) has long been considered a serious environmental problem that can affect the integrity of natural communities, influence mechanisms which include competition, predation and parasitism, and alter food webs and nutrient cycles (Vitousek, 1990; Carlton \& Geller, 1993; Lodge, 1993; Grosholz \& Ruiz, 1996; Lafferty \& Kuris, 1996; Crooks, 1998). Thus, the introduction of exotic species has changed the species composition of many marine communities (Carlton, 1987).

According to Connell, (1961), space is an important limiting factor for sessile marine organisms. Competitive interactions among benthic organisms for space in marine communities can be intense and are frequently manifested as overgrowth of adjacent individuals and epibiosis (Koh \& Sweatman, 2000). To understand the possible impacts of an introduced species on an established community and predict its potential for establishment and range expansion to new areas, quantitative and experimental studies are needed (Carlton, 1996). These should identify the ecological preferences of exotic species so that their potential for new invasions can be inferred.

Laborel $(1967,1969,1970)$ was the first to describe the geographical distribution of the scleractinian corals along the Brazilian coast. Subsequently, other studies described the distribution of native corals on Brazil's rocky shores (Pitombo et al., 1988; Castro et al., 1995; Castro et al., 1999), as well as their distribution according to substratum angles (Segal \&
Castro, 2000). The ahermatypic coral Tubastraea Lesson, 1829 is a Scleractinia nonindigenous to the South Atlantic and was probably introduced in Brazil in the late 1980's (Castro \& Pires, 2001), when the first observations were made on an oil platform operating in the Campos Basin in the northern region of the state of Rio de Janeiro. Ilha Grande Bay is a shipping lane (shipping traffic and oil platforms) which probably brought these corals to the region. This azooxanthellate coral, which grows on shallow-water rocky shores, is generally absent from areas of dense coral growth (Wood, 1983), preferring protected shores with little hydrodynamism (Prahl, 1987; Cairns, 1991, 1994). Although the genus is cosmopolitan, there is little information about factors that affect its spatial distribution and variability. The current range expansion of Tubastraea in Ilha Grande offers a rare opportunity to compile information on the insertion of this exotic coral into a tropical rocky shore community.

The aims of the present study were to map the distribution and abundance of the coral genus Tubastraea in Ilha Grande, Brazil and to identify and quantify aspects of its local spatial distribution.

Because the genus is exotic to southwest Atlantic waters and considering that variations in the morphology of Tubastraea were observed along the Ilha Grande coastline, the present study was carried out conservatively at the genus level.

\section{MATERIAL AND METHODS}

\section{Study site}

Ilha Grande is an island lying $23^{\circ} \mathrm{S}$ and $44^{\circ} \mathrm{W}$ on the southern coast of Rio de Janeiro state, Brazil (Fig. 1). Ilha Grande Bay, which is enclosed by the island, was subdivided into three units, Porção Oeste, Canal Central, and Porção Leste (Mahiques 


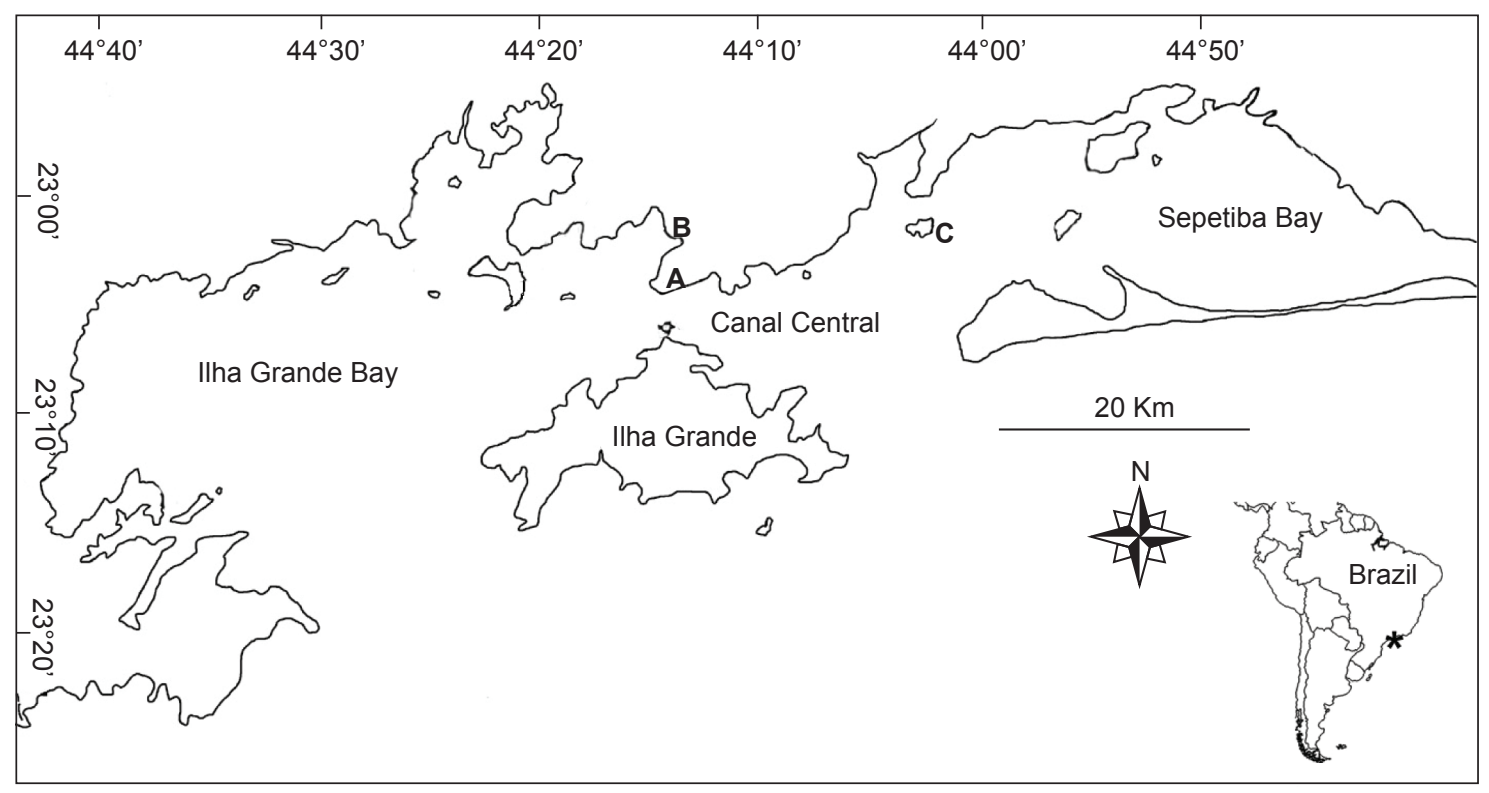

Fig. 1 - Map of study area. A) Petrobras oil terminal; B) Verolme shipyard; and C) Ilha Guaiba Port.

\& Furtado, 1989) and contains 365 islands. Ikeda et al. (1989) suggested that the region be classified as a partially mixed estuarine system combining the Ilha Grande and Sepetiba Bays (Sepetiba is an estuarine body of water connected to Ilha Grande Bay on its eastern side, which provides most of the fresh water to the region, Fig. 1). Even so, salinity remains stable at 35-36. Between the island and the continent is a channel (the Canal Central) used intensively as a shipping lane and dotted by a few oil platforms. There is an oil terminal on the continent facing Ilha Grande at Monsuaba, a shipyard at Jacuacanga and a mineral ore terminal which receives international shipping traffic at Ilha Guaiba (Fig. 1).

The sites studied were located on the inner side of Ilha Grande along the Canal Central, on rocky shores or boulder field reefs that give way to a sedimentary (sand) plain which starts at a 3-7 $\mathrm{m}$ depth. Because of the reduced circulation, small tidal amplitude $(1.4 \mathrm{~m})$ and restricted fetch, the shores are protected, with little water movement. In summer, the water temperature rises as warm water from nearby regions flows into the Bay. Consequently, through the year, the temperature of the tropical waters in Ilha Grande varies from 21 to $32{ }^{\circ} \mathrm{C}$.

\section{Distribution and abundance with depth}

To map the general distribution and relative abundance of Tubastraea, a semi-quantitative method was used at 37 locations between Praia de Palmas (Pouso) and Ponta do Acaiá (Fig. 2) during 2000. At each location, two snorkel divers spent three periods of 1 min underwater, subjectively evaluating the relative abundance of Tubastraea, which was classified as: Dominant $>$ Abundant $>$ Frequent $>$ Occasional $>$ Rare $>$ or Absent. A relative abundance index was created by scoring these categories as 10, 8, 6, 4, 2 and zero, respectively.

To describe the abundance of Tubastraea with depth, five stations were selected: Ilha dos Macacos, Ilha Aroeira, Ilha Redonda, Costão do Bananal and Lagoa Azul. Using SCUBA, belt transects were located randomly along the shore perpendicularly to the water line and quadrats $(50 \times 50 \mathrm{~cm})$ were used to sample continuously down the transects from the water level to the sediment plain. Three sampling methods were used: colony density, and visual estimation and intercept points (100) for percentage of cover. The depth of each quadrat was recorded. Quadrats were grouped into $0.5 \mathrm{~m}$ depth intervals and the mean percentage covers and density calculated. 


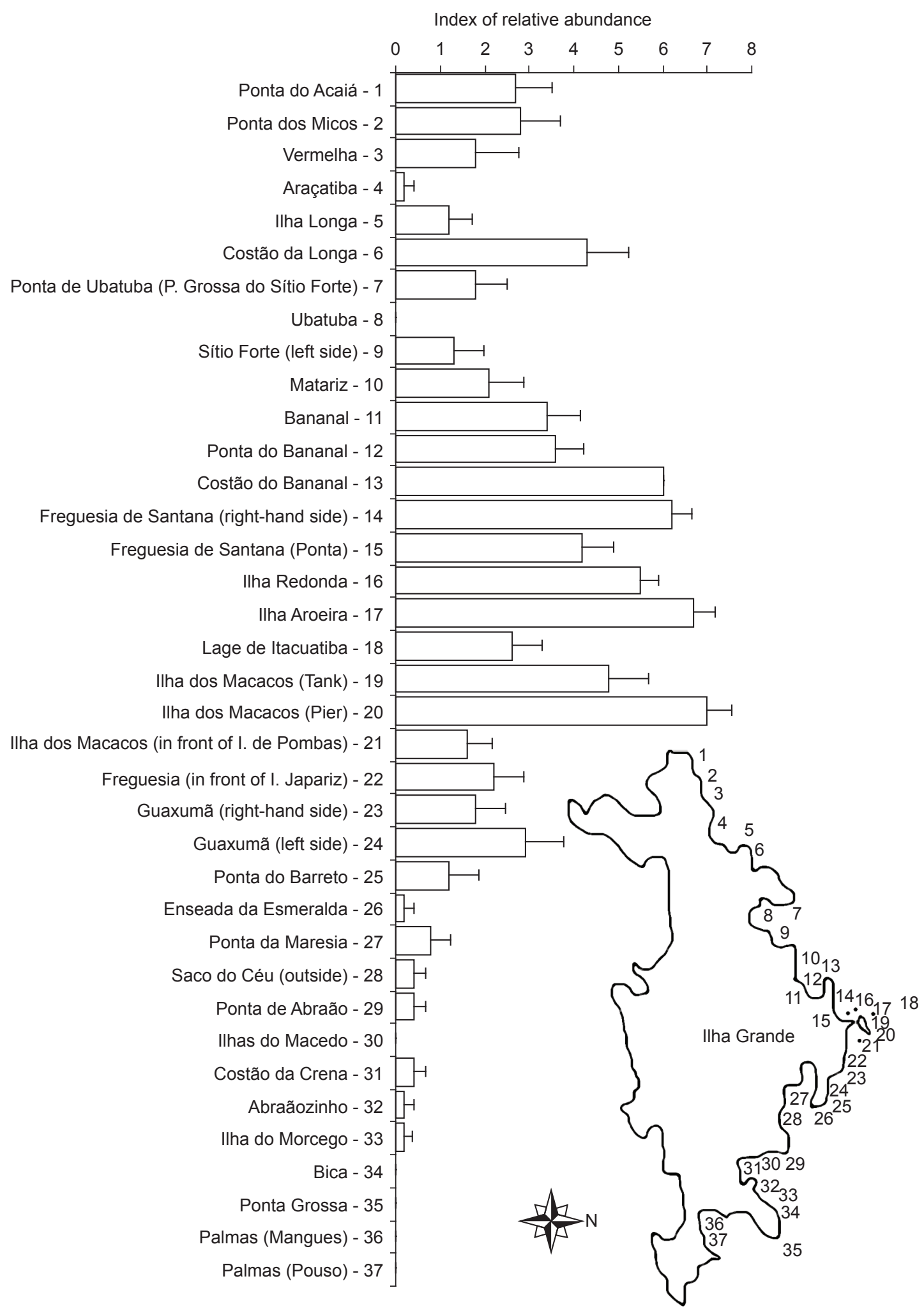

Fig. 2 - Tubastraea sample site and general distribution and abundance in the Canal Central of Ilha Grande Bay (RJ), Brazil. 
The three methods used to quantify abundance were found to be equivalent, since the Spearman correlation coefficients considering sites separately were: intersection - density $(r=0.78-0.89)$; subjective estimate - density $(r=0.75-0.96)$; intersection - subjective estimate $(r=0.72-0.94), n=165, p<0.001$ in all cases.

\section{Slope preference}

To characterize the slope preference of Tubastraea on the rocky shores, data were collected randomly at 3 stations. The angle of the substratum was determined with a graduated arc and a float. 206 colonies were measured: Comprida $(n=33)$; Macacos $(n=46)$; Aroeira $(n=127)$.

\section{RESULTS}

\section{General geographical distribution and abundance}

Tubastraea was found over a substantial geographical range on the rocky shores of Canal Central in Ilha Grande, extending from Ponta do Acaiá (in the west) to Ilha do Morcego (in the east), a distance of $25 \mathrm{~km}$. The coral was not found at Bica, Ponta Grossa and two points at Palmas beach (Fig. 2).

Based on the semiquantitative method of relative abundance, the site with the greatest abundance of the coral was situated at Ilha dos Macacos (Fig. 2). In both directions (east and west), the abundance of Tubastraea decreased as the distance from Ilha dos Macacos increased (Fig. 2). A negative correlation of relative abundance index and distance from the Petrobras oil terminal (Fig. 3A) and the Verolme shipyard (Fig. 3B) was found, but no correlation was found between the relative abundance of Tubastraea and the Ilha Guaiba terminal (Fig. 3C).

The overall mean density of Tubastraea at all Ilha Grande sites was 9.55 colonies. $0.25 \mathrm{~m}^{-2}$. The values per $\mathrm{m}^{2}$ were: Macacos (4.54), Aroeira (20.7), Redonda (7.75), Bananal (0.27), and Lagoa Azul (4.95).

\section{Depth profiles and abundance}

Despite the availability of hard substratum down to a 6-7 $\mathrm{m}$ depth, Tubastraea was found in the greatest abundance at shallow depths. The maximum mean percentage cover of Tubastraea was 18.5 and $11.3 \%$ (visual estimate and intercept point methods, respectively) at Aroeira at a 0.1-0.5 m depth. The maximum mean colony density $\left(191.6 \mathrm{~m}^{-2}\right)$ was also found at the same site and depth (Fig. 4). The maximum cover of Tubastraea found in any quadrat was $80 \%$ and the maximum density was 792 colonies. $\mathrm{m}^{-2}$. The depth at which Tubastraea was most abundant was shallower still: - 0.4-0 m at Bananal, so the coral was quite regularly exposed to air at all these locations (Fig. 4). With respect to number of colonies, the greatest abundance of Tubastraea was found at a 0.6-1.0 m depth in Lagoa Azul (Fig. 4).

\section{Frequency of density of Tubastraea}

Considering the data for colony densities taken from the depth profiles, the distribution of colonies was quite variable. At most sites, $1-5$ colonies were most frequently found per quadrat of $0.25 \mathrm{~m}^{-2}$ (Fig. 5). However, it was not uncommon to find quadrats with more than 50 colonies. Considering all stations, Tubastraea densities of more than 50 colonies. $0.25 \mathrm{~m}^{-2}$ were found in $7.4 \%$ of quadrats. One quadrat at Lagoa Azul contained 283 colonies (1132 colonies. $\mathrm{m}^{-2}$ ). This indicates that the spatial distribution of Tubastraea colonies at five of the stations studied was highly gregarious. At Bananal, which showed the lowest abundance of Tubastraea, no quadrat contained more than 25 colonies.

\section{Substratum angle}

Tubastraea was found to occupy slopes of every possible angle in the Canal Central of Ilha Grande. More colonies were found occupying slopes of $80-100^{\circ}(22 \%)$ than other angles. $12 \%$ of the colonies occupied slopes at angles of 91-100 (Fig. 6).

\section{DISCUSSION}

The global movement of organisms associated with seafaring vessels and with commercial fishery products have redistributed a vast number of marine organisms. Carlton $(1987,1989)$ stated that introductions frequently consist of the transportation of organisms across natural barriers by human activity (different from natural range expansions) and that the main mechanism of dispersal of species is shipping (fouling and ballast). The transportation of marine organisms 
A) Petrobras oil Terminal

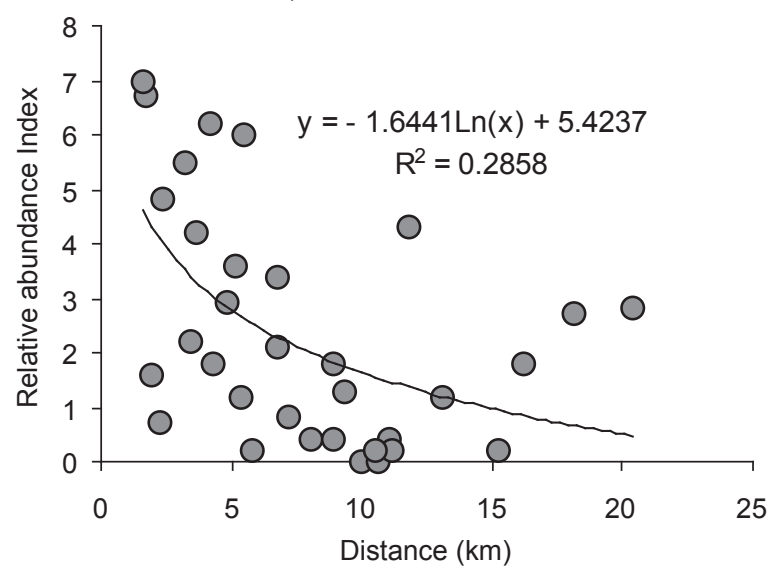

B) Verolme Shipyard

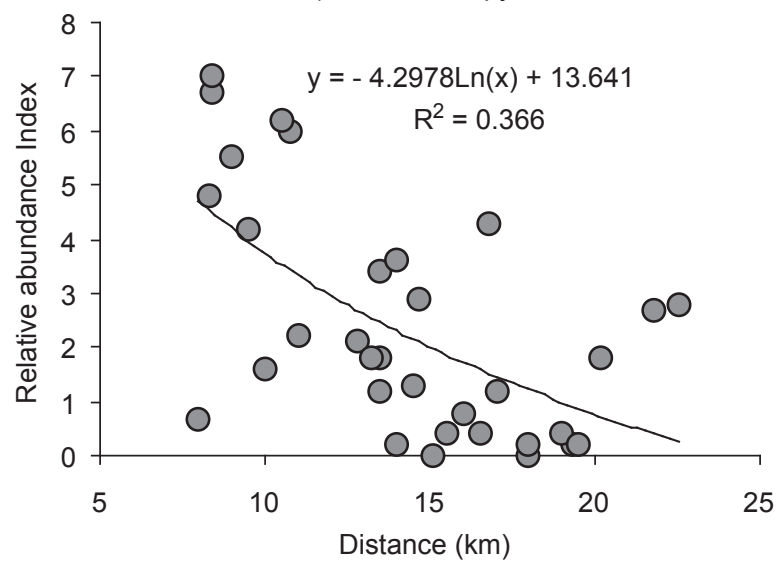

C) Ilha Guaiba Terminal

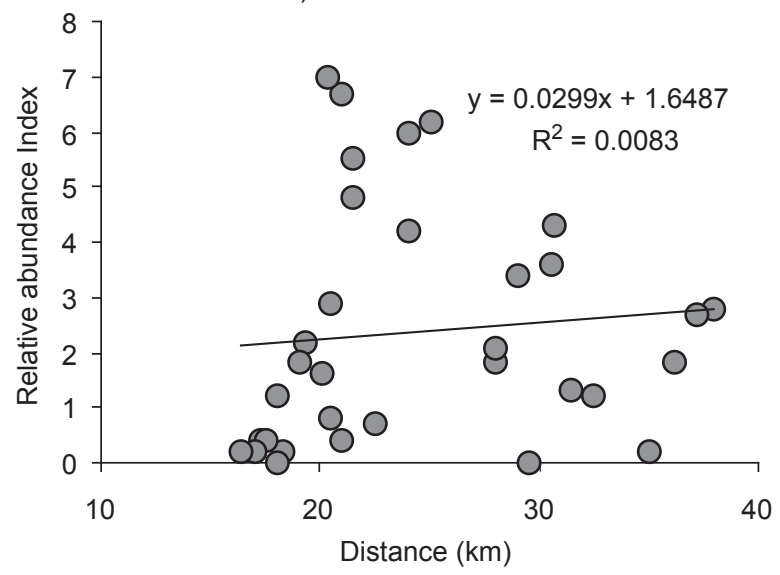

Fig. 3 - Tubastraea. Abundance as a function of distance from A) Petrobras oil terminal; B) Verolme shipyard; and C) Ilha Guaiba Port (RJ), Brazil. 


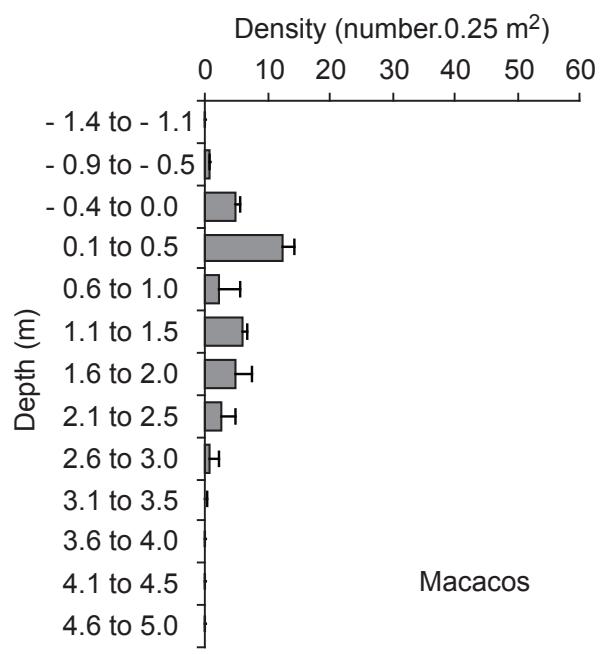

Density (number. $0.25 \mathrm{~m}^{2}$ )
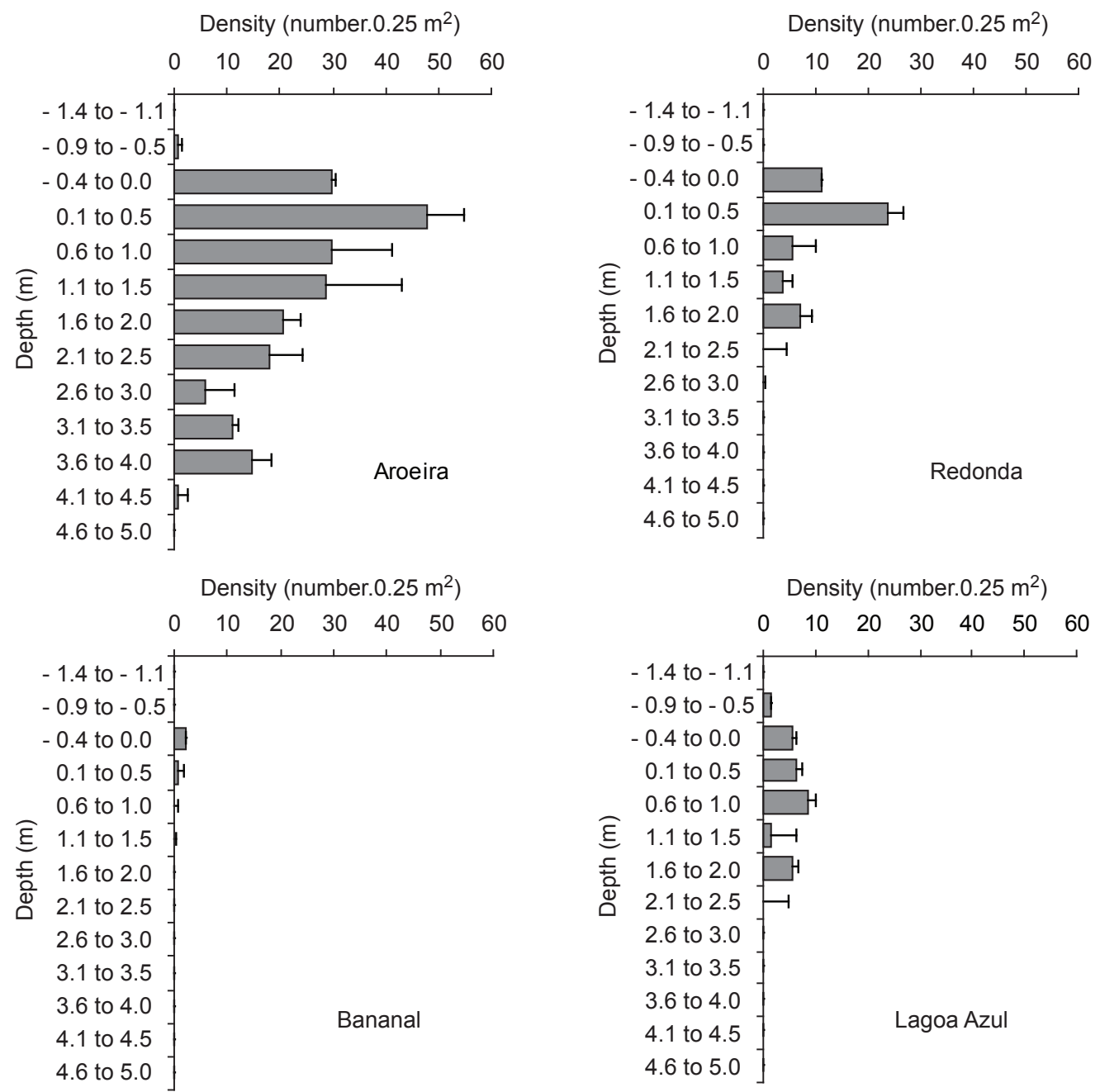

Fig. 4 - Colony density as a function of depth at five locations at Ilha Grande, Brazil. Data are mean values for each depth, bars $=$ S.E. 

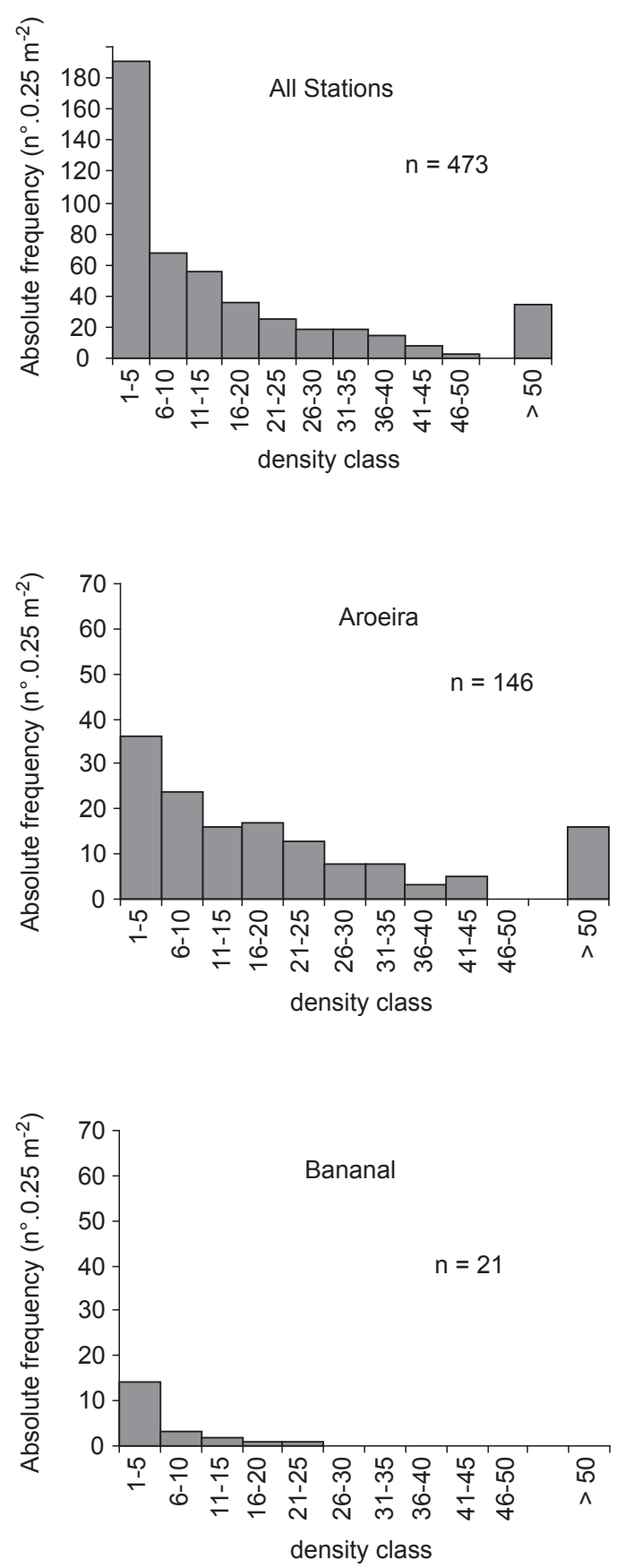
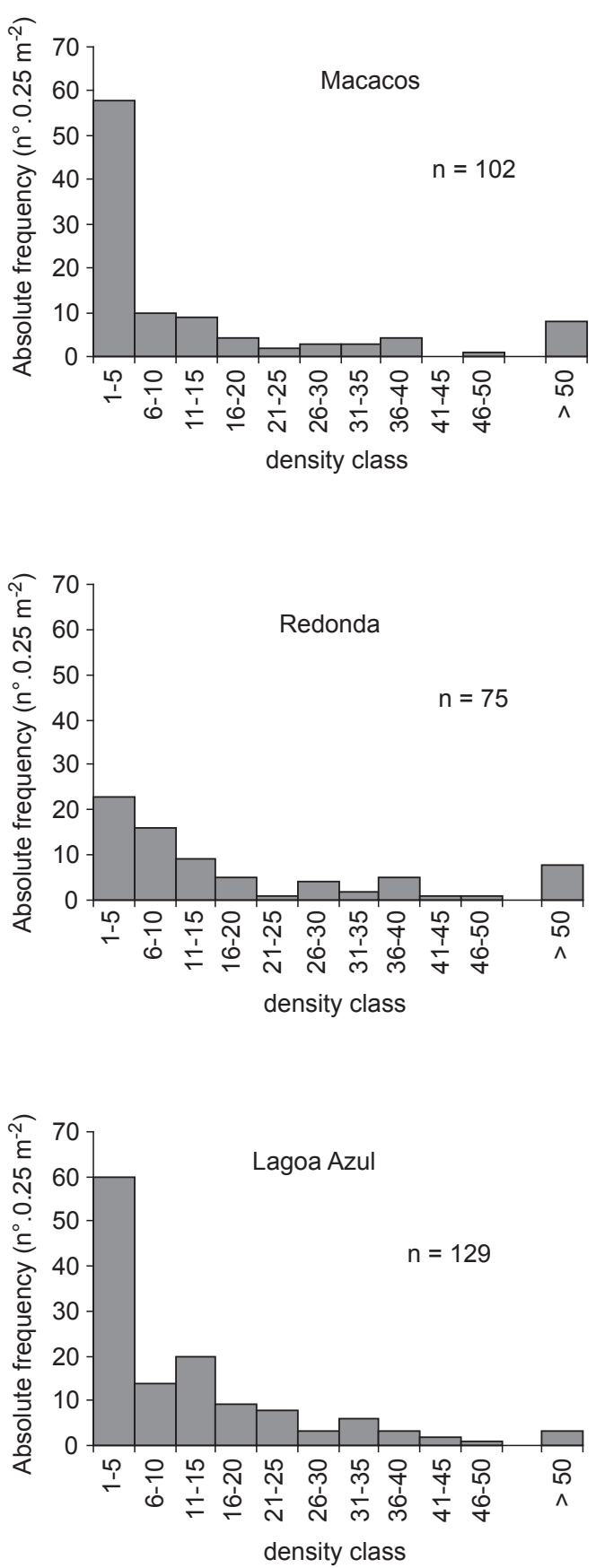

Fig. 5 - Tubastraea. Frequency of quadrats containing different densities of colonies at five locations and all stations, Ilha Grande (RJ), Brazil.

by oil platforms has been considered less often as responsible for the introduction and dispersal of nonindigenous species. The introduction of exotic species has long been recognized as serious environmental problem affecting the integrity of natural communities (Vitousek, 1990; Carlton \& Geller, 1993; Lodge, 1993; Grosholz \& Ruiz, 1996, Lafferty \& Kuris, 1996; Crooks, 1998). 


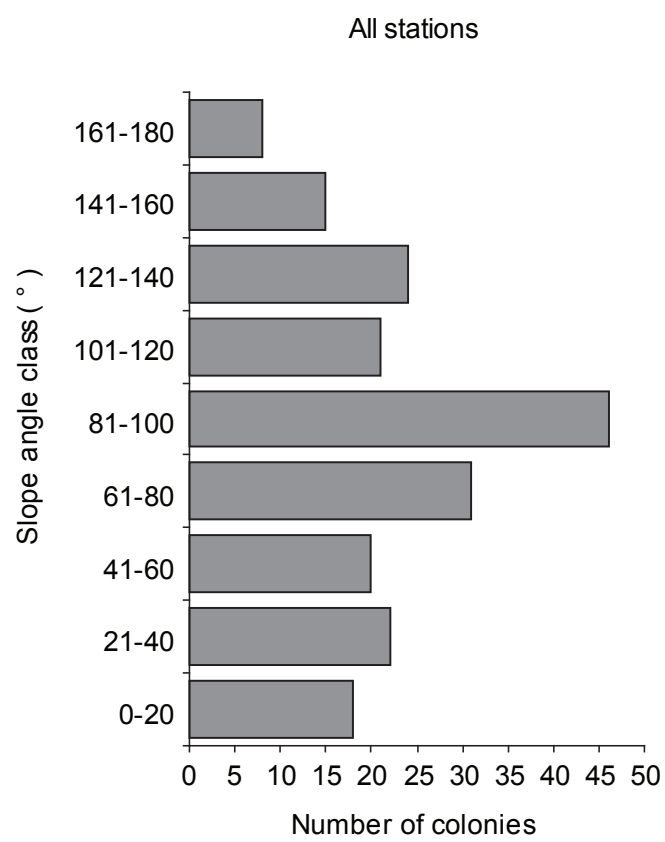

Fig. 6 - Tubastraea. Distribution of colonies on rocky substrata of different angles in Canal Central, Ilha Grande $(\mathrm{n}=206)$.

Tubastraea has demonstrated the ability to colonize and rapidly expand its range. It is the first scleractinian coral known to be introduced to Brazil. The present study is the first one to quantify aspects of its distribution and abundance. Tubastraea was initially reported in the western Atlantic in 1943, but today the coral has not only expanded its range to the entire Caribbean region but also its local abundance (Cairns, 2000). Although this coral occurs in the western and eastern Atlantic, Indian Ocean, western and central Pacific and eastern Pacific Oceans (Cairns et al., 1998), new records of Tubastraea confirm that this coral is a successful invasive organism and may be considered an opportunist because of its rapid range expansion and rising abundance in newly colonized areas (Cairns, 2000).

This coral has frequently been observed attached to ship's hulls (Cairns, 1994, 2000) and oil platforms (Fenner, 2001). On a checklist of the ahermatypic Scleractinia of the Gulf of Mexico, Cairns (1978) did not find Tubastraea in the region, although Fenner (1999) observed this coral in the Caribbean (Cozumel and Belize) and later on oil platforms in the Gulf of Mexico (Fenner, 2001). Tubastraea has therefore broadened its distribution in the western Atlantic (Cairns, 2000).
The data of this study show that the coral Tubastraea has been introduced to Brazil and has expanded its range throughout Ilha Grande. It has become well established and may be the dominant sessile benthic organism on the rocky shores. The coral arrived in Brazil around 1980 and today occupies a $25 \mathrm{~km}$ stretch of coastline in the Canal Central. The greater abundance of this coral near the Petrobras oil terminal and Verolme shipyard suggest that these are potential points of introduction of the coral. Both Ilha Grande and Sepetiba Bay are areas with intense shipping traffic and oil platforms, which may bring encrusting exotic species to the region. The range of Tubastraea has expanded at Ilha Grande, although Castro et al. (1999), who studied the distribution of Cnidaria at Ilha Grande in some of the same locations sampled in this study, did not report this, probably because the coral was less widely distributed at the time of their study (1993). At the preferred depth of Tubastraea, those authors found Palythoa caribaeorum, the very common zoanthid at Ilha Grande, to be the most abundant organism.

The density of Tubastraea was very variable and although most quadrats had lower densities, $7.4 \%$ of all quadrats measured contained more than 50 colonies. $0.25 \mathrm{~m}^{-2}$, while some quadrats 
displayed more than 100 colonies and one had 283 colonies. $0.25 \mathrm{~m}^{-2}$. These values are the highest ones reported for corals in Brazilian waters, as Leão et al. (1997) found 0.3-4 colonies of scleractinian corals. $\mathrm{m}^{-2}$ in Northern Bahia, while Maida et al. (1995) found a mean value of 6.62 colonies of Siderastrea stellata. $\mathrm{m}^{-2}$ in the Fernando de Noronha Archipelago. The density values found here were extremely high (200-fold) even when compared with the density of scleractinian corals in coral rich regions such as the Caribbean, where Goodwin et al. (1976) found 0.04-6.53 colonies.m², Lewis (1997) found 0.002-0.06 colonies. $\mathrm{m}^{-2}$, and Carlon (2002) found 1-4 colonies.m ${ }^{-2}$ of Favia fragum.

Tubastraea was absent from the Bica and Ponta Grossa stations, where the rocky shores have steep solid rock slopes dominated by calcareous algae and urchins and are considerably exposed. The coral was also absent from Palmas (Mangues) and Palmas (Pouso), located at the extreme east of the study points. The coral has probably not yet colonized these shores. The only other station where Tubastraea was not found was Ubatuba, which is situated between other locations where the coral was found in abundance. Ubatuba is situated near the mouth of a river, so the salinity is probably lower, possibly influencing the coral's local settlement or survival.

Sebens \& Done (1992) suggested that coral distribution and abundance may be controlled by the interaction of biological and physical factors and by historical effects. At Ilha Grande, Tubastraea showed a broad tolerance for temperature (surface water reached $32^{\circ} \mathrm{C}$ in summer) and desiccation, as indicated by its abundance in very shallow waters occasionally exposed to air (0.1-0.5 m), although hard substratum was available a greater depths at every station.

The spatial distribution in scleractinian corals has been described in several reports, particularly with regard to depth (Birkeland, 1977; Miller, 1995; Babcock \& Mundy, 1996; Mundy \& Babcock, 1998) and angle of settlement or recruitment (Bak \& Engel, 1979; Carleton \& Sammarco, 1987; Babcock \& Mundy, 1996; Segal \& Castro, 2000), which are considered important factors influencing scleractinian settlement and survival. Tubastraea was found most abundantly at very shallow depths (the littoral fringe/shallow sub- tidal), which is considered a stressful environment because of sudden changes in various environmental and biological factors. At Ilha Grande, the great abundance of Tubastraea colonies in shallow waters suggests that shallow depths benefited their recruitment or survival. A correlation between abundance and depth has been reported previously, for example, by Bak \& Engel (1979) and Mundy $\&$ Babcock (2000). Higher sedimentation rates or mobility of sediment with depth, because of the sediment plain, may also explain why Tubastraea grew most abundantly at shallow depths. However, the ecological processes that explain population distribution and abundance cannot be understood until the organisms' patterns are well documented (Underwood et al., 1991).

Because Tubastraea is an asymbiotic, azooxanthellate coral, it does not have a photosynthetic requirement for light. However, it favors the growth or limits the distribution of other organisms such as macroalgae and turf algae (Jania spp., Padina spp. and Laurencia spp.) and the zoanthid Palythoa caribaeorum, which were abundant at shallower depths in the study area and are potential competitors of scleractinian corals (Tanner, 1995). At Ilha Grande, Tubastraea appears to resist overgrowth, remaining healthy amongst algal turfs (unpublished data from experiments and in situ observations).

Tubastraea has been described as a coral that occurs preferentially on overhangs or drop-offs (Wood, 1983; Prahl, 1987; Cairns, 1991, 1994; Reyes-Bonilla et al., 1997). At Ilha Grande, this coral showed great plasticity in slope use, but was most commonly found on $80-100^{\circ}$ substratum angles. It must be noted, however, that several colonies could not be measured because of the difficulty in sampling all the colonies occurring in caves, grooves and crevices, and this artifact may have resulted in an underestimation of the preferred slope angle of Tubastraea.

Tubastraea was found at every possible slope angle, so it was able to recruit to all surface angles. Mundy (2000), who stated that coral larvae may prefer particular angles within microhabitats during settlement and/or that the survival of recruits may be dependent on the angle of the microhabitat, did not find an angle effect on coral recruitment density on artificial substrata. This finding is incongruent with that of Carleton \& Sammarco (1987), who found 
significantly more recruits on artificial substrata angled between $61^{\circ}-90^{\circ}$. Segal and Castro (2000) found species specific preference for different substratum slopes in the Abrolhos Archipelago, Brazil. In Curaçao, Bak \& Engel (1979) found very few juveniles of scleractinia corals on undersurfaces (2\%) and no divergence in survival on different angles of substratum. It seems that, at Ilha Grande, Tubastraea preferred certain angles but maintained the ability to exploit any available substratum.

The nonindigenous coral was observed to be overgrown by other organisms such as sponges and ascidians, which have been reported as coral competitors in shallow waters (Dunstan \& Johnson, 1998). Other organisms such as bryozoans, barnacles and calcareous algae, all of which are considered r species (Birkeland, 1977) were found to grow together with Tubastraea, suggesting that this coral is very competitive on hard substrata in shallow waters. Tubastraea also seemed highly competent in occupying empty spaces on the rocky shores of Ilha Grande and occurred together with some Cnidaria such as Zoanthus sp., Palythoa caribaeorum, Phyllangia americana, Astrangia rathbuni, Mussismilia hispida and Carijoa riisei, all of which can be considered potential competitors.

Tubastraea has been recognized as an invasive coral. In Ilha Grande, Brazil, its distribution suggests that it was introduced to the region by ships or oil platforms, whereupon it rapidly increased its range. The distributional data suggest that it is an organism that can exploit unoccupied hard substrata, even when these are created by regular disturbance events. Once established, it appears to be competitively superior and, although it shows specific substratum angle and depth preferences at Ilha Grande, it is tolerant to major variations in these parameters. Although many of these observations should and will be validated or rejected in future experiments, the spatial distribution and abundance data presented here suggest that the Tubastraea at Ilha Grande is highly suited to continue its current range expansion in Brazil.

Acknowledgements - We would like to thank L. Vidal, S. Oigman, V. Palermo, A. Oliveira, and M. Figueiredo of the Benthic Marine Ecology Laboratory/Universidade do Estado do Rio de Janeiro and Museu Nacional/Universidade Federal do Rio de Janeiro for their assistance in the field work, our irreplaceable skipper Mr. Ramos, and the Center for Environmental Studies and Sustainable Development - CEADS/UERJ for the use of its staff and facilities, which made this study possible. JCC was the recipient of a grant from the Conselho Nacional de Desenvolvimento Científico e Tecnológico (CNPQ, Brazil) and AFP from the Fundação Carlos Chagas Filho de Amparo à Pesquisa do Estado do Rio de Janeiro (FAPERJ, Brazil) during this study.

\section{REFERENCES}

BABCOCK, R. C. \& MUNDY, C. N., 1996, Coral recruitment: consequences of settlement choice for early growth and survivorship in two scleractinians. J. Exp. Mar. Biol. Ecol., 206: 179-201.

BAK, R. P. M. \& ENGEL, M. S., 1979, Distribution, abundance and survival of juvenile hermatypic corals (Scleractinia) and the importance of life history strategies in the parent coral community. Mar. Biol., 54: 341-352.

BIRKELAND, C., 1977, The importance of rate of biomass accumulation in early successional stages of benthic communities to the survival of coral recruits. Proc. 3 th Int. Coral Reef Symp., 1: 15-21.

CAIRNS, S. D., 1978, A checklist of the ahermatipic scleractinia of the Gulf Mexico, with the description of a new species. Gulf Research Reports, 6: 9-15.

CAIRNS, S. D., 1991, A revision of the ahermatypic Scleractinia of the Galápagos and Cocos islands. Smithson. Contrib. Zool., 504: 1-56.

CAIRNS, S. D., 1994, Scleractinia of the temperate North Pacific. Smithson. Contrib. Zool., 557: 1-150.

CAIRNS, S. D., 2000, A revision of the shallow-water azooxanthellate Scleractinia of the Western Atlantic. Stud. Nat. Hist. Caribb., 75: 1-240.

CAIRNS, S. D., HOEKSEMA, B. W. \& VAN DER LAND, J., 1998, List of extant stony corals Internetadress: http://www.nodc.noaa.gov/col/projects/coral/hardcoral/ Hardcoralmain. html.

CARLETON, J. H. \& SAMMARCO, P. W., 1987, Effects of substratum irregularity on success of coral settlement: quantification by comparative geomorphological techniques. Bull. Mar. Sci., 40: 85-98.

CARLON, D. B., 2002, Production and supply of larvae as determinants of zonation in a brooding tropical coral. $J$. Exp. Mar. Biol. Ecol., 268: 33-46.

CARLTON, J. T., 1987, Patterns of transoceanic marine biological invasions in the Pacific Ocean. Bull. Mar. Sci., 41: 452-465.

CARLTON, J. T., 1989, Man's role in changing the face of the ocean: biological invasions and implications for conservation of near-shore environments. Conservation Biology, 3: 265-273.

CARLTON, J. T. \& GELLER, J. B., 1993, Ecological roulette: the global transport of nonindigenous marine organism. Science, 261: 78-82.

CARLTON, J. T., 1996, Pattern, process, and prediction in marine invasion ecology. Biological Conservation, 78 : 97-106.

CASTRO, C. B., ECHEVERríA, C. A., PIRES, D. O., MASCARENHAS, B. J. A. \& FREIRAS, S. G., 1995, 
Distribuição de Cnidaria e Echinodermata no infralitoral de costões rochosos de Arraial do Cabo, Rio de Janeiro, Brasil. Rev. Brasil. Biol., 55: 471-480.

CASTRO, C. B., ECHEVERRÍA, C. A., PIRES, D. O. \& FONSECA, C. G., 1999, Distribuição do Bentos (Cnidaria e Echinodermata) em costões rochosos da Baía da Ilha Grande, Rio de Janeiro, Brasil. In: S.H.G. Silva \& H.P. Lavrado (eds.) Ecologia dos ambientes costeiros do Estado do Rio de Janeiro. Série Oecologia Brasiliensis, vol VII. PPGE-UFRJ. Rio de Janeiro, Brasil, 179-193 p.

CASTRO, C. B. \& PIRES, D. O., 2001, Brazilian coral reefs: what we already know and what is still missing. Bull. Mar. Sci., 69: 357-371.

CONNELL, J. H., 1961, The influence of interspecific competition and other factors on the distribution on the barnacle Chthamalus stellatus. Ecology, 42: 710-723.

CROOKS, J. A., 1998, Habitat alteration and community-level effects of an exotic mussel, Musculista senhousia. Mar. Ecol. Prog. Ser., 162: 137-152.

DUNSTAN, P. K., JOHNSON, C. R., 1998, Spatio-temporal variation in coral recruitment at different scales on Heron Reef, southern Great Barrier Reef. Coral Reefs, 17: 71-81.

FENNER, D., 1999, New observations on the stony coral (Scleractinia, Milleporidae, and Stylasteridae) species of Belize (Central America) and Cozumel (Mexico). Bull. Mar. Sci., 64: 143-154.

FENNER, D., 2001, Biogeography of three Caribbean corals (Scleractinia)and a rapid range expansion of Tubastraea coccinea into the Gulf of Mexico. Bull. Mar. Sci., 69: 1175-1189.

GOODWIN, M. H., COLE, M. J. C., STUART, W. E. \& ZIMMERMAN, B. L., 1976, Species density and associations in Caribbean reef corals . J. Exp. Mar. Biol. Ecol., 24: 19-31.

GROSHOLZ, E. D., RUIZ, G. M., 1996, Predicting the impact of introduced marine species: lessons from the multiple invasions of the European Green Crab Carcinus maenas. Biological Conservation, 78: 59-66.

IKEDA, Y., GODOI, S. S. \& CACCIARI, P. L., 1989, Um estudo de séries temporais de corrente na Baía da Ilha Grande. Relat. Int. Inst. Oceanogr. Univ.S. Paulo, 28: 1-24.

JOHNSON, L. E. \& CARLTON, J. T., 1996, Post-establishment spread in large-scale invasions: dispersal mechanisms of the Zebra Mussel Dreissena polymorpha. Ecology, 77: 1686-1690.

KOH, E. G. L. \& SWEATMAN, H., 2000, Chemical warfare among scleractinians: bioactive natural products from Tubastraea faulkneri Wells kill larvae of potential competitors. J. Exp. Mar. Biol. Ecol., 251: 141-160.

LAFFERTY, K. D. \& KURIS, A. M., 1996, Biological control of marine pests. Ecology, 77: 1989-2000.

LABOREL, J., 1967, A revised list of Brazilian scleractinian corals and description of a new species. Postilla, 107: 1-14.

LABOREL, J., 1969, Les peuplements de madréporaires des côtes tropicales du Brésil. Annales de l'Université d'Abidjan (E), 2: 1-260.

LABOREL, J., 1970, Madréporaires et Hydrocoralliaires récifaux des cotes brésilienes. Sistématique, écologie, repartition verticale et géographique. Annales de l'Institut Océanographique, Mônaco, 47: 171-29.

LEÃO, M., KIKUCHI, R. K. I. P., MAIDA, M. P. \& LAGO, R. A. L., 1997, A catastrophic coral cover decline since 3,000 years B. P., northern Bahia, Brazil. Proc. $8^{\text {th }}$ Int. coral Reef Symp., 1: 583-588.

LEWIS, J. B., 1997, Abundance, distribution and partial mortality of the massive coral Siderastrea siderea on degrading coral reefs at Barbados, west Indies. Mar. Poll. Bull., 34: 622-627.

LODGE, D. M., 1993, Species invasions and deletions: community effects and responses to climate and habitat change. In: P. M. Kareiva, J. G. Kingsolver \& R. B. Huey (eds.). Biotic interactions and global change. Sinauer, Massachusetts, 367-387 p.

MAHIQUES, M. M. \& FURTADO, V. V., 1989, Utilização da análise dos componentes principais na caracterização dos sedimentos de superfície de fundo da Baía da Ilha Grande (RJ). Bol. Inst. Oceanogr. S. Paulo, 37: 1-19.

MAIDA, M., FEREIRA, B. P. \& BELLINI, C., 1995, Avaliação preliminar do recife da Baía do Sueste, Fernando de Noronha, com ênfase nos corais escleractíneos. Bol. Tecn. CEPENE, 3: 37-47.

MILLER, M. W., 1995, Growth of a temperate coral: effects of temperature, light, depth, and heterotrophy. Mar. Ecol. Prog. Ser., 122: 217-225.

MUNDY, C. N., 2000, An appraisal of methods used in coral recruitment studies. Coral Reefs, 19: 124-131.

MUNDY, C. N. \& BABCOCK, R. C., 1998, Role of light intensity and spectral quality in coral settlement: implications for depth-dependent settlement? J. Exp. Mar. Biol. Ecol., 223: 235-255.

MUNDY, C. N. \& BABCOCK, R. C., 2000, Are vertical distribution patterns of scleractinian corals maintained by pre- or post-settlement processes? A case study of three contrasting species. Mar. Ecol. Prog. Ser, 198: 109-119.

PITOMBO, F. B., RATTO, C. C. \& BELEM, M. J. C., 1988 , Species diversity and zonation pattern of hermatypic corals at two fringing reefs of Abrolhos Archipelago, Brazil. Proc. 6th Int. Coral Reef Symp., 2: 817-820.

PRAHL, H. V., 1987, Corales ahermatípicos colectados en el Pacífico Colombiano. Rev. Biol. Trop., 35: 227-232.

REYES-BONILLA, H., PÉREZ-VIVAR, T. L. \& KETCHUM, J. T., 1997, Nuevos registros del coral ahermatípico Tubastraea coccinea Lesson, 1829 (Scleractinia: Dendrophyllidae) en el Pacífico de México. Rev. Inv. Cient. Ser. Cienc. Mar. UABCS, 8: 31-33.

SEBENS, K. P. \& DONE T. J., 1992, Water flow, growth form and distribution of scleractinian corals: Davis Reef (GRB), Australia. Proc. $7^{\text {th }}$ Int. Coral Reef Symp. Guam, 1557-1568.

SEGAL, B. \& CASTRO, C.B., 2000, Slope preferences of reef corals (Cnidaria, Scleractinia) in the Abrolhos Archipelago, Brazil. Boletim do Museu Nacional de Rio de Janeiro, 418: $1-10$.

TANNER, J. E., 1995, Competition between scleractinian corals and macroalge: An experimental investigation of 
coral growth, survival and reproduction. J. Exp. Mar. Biol. Ecol., 190: 151-168.

UNDERWOOD, A. J., KINGSFORD, M. J. \& ANDREW, N. L., 1991, Patterns in shallow subtidal marine assemblages along the coast of New South Wales. Australian Journal of Ecology, 8: 231-249.
VITOUSEK, P. M., 1990, Biological invasions and ecosystem processes: towards an integration of population biology and ecosystem studies. Oikos, 57: 7-13.

WOOD, E. M., 1983, Corals of the world. T.F.H. Publications. Inc. New Jersey, $256 \mathrm{p}$. 